\title{
Exploration of National Tourism Development, Innovation and Marketing Policies: A Case Study of Nepal Tourism Constraints
}

\author{
Lochan Kumar Batala1, Kalpana Regmi'2, GiriRaj Sharma1, Azmat Ullah ${ }^{3}$ \\ ${ }^{1}$ School of Public Administration, University of Science and Technology, Hefei, China \\ ${ }^{2}$ School of Economics and Management, Anhui Agriculture University, Hefei, China \\ ${ }^{3}$ Department of Management Science and Engineering, Shanghai Jiao Tong University, Shanghai, China \\ Email: lochan@mail.ustc.edu.cn
}

How to cite this paper: Batala, L.K., Regmi, K., Sharma, G. and Ullah, A. (2019) Exploration of National Tourism Development, Innovation and Marketing Policies: A Case Study of Nepal Tourism Constraints. American Journal of Industrial and Business Management, 9, 403-425.

https://doi.org/10.4236/ajibm.2019.92027

Received: January 24, 2019

Accepted: February 25, 2019

Published: February 28, 2019

Copyright $\odot 2019$ by author(s) and Scientific Research Publishing Inc. This work is licensed under the Creative Commons Attribution International License (CC BY 4.0).

http://creativecommons.org/licenses/by/4.0/

\begin{abstract}
The main purpose of this study was to construct a sought-on tourism innovation \& tourism marketing strategies which are essential tools for development of tourism industry for a particular tourism resource nation. This paper centrally focused on Nepalese tourism development constraints discourse by emphasizing the context of innovation and marketing. The data were derived from multiple sources such as: field observation, review of multiple public sectors tourism institution's policy and plan documents, questionnaire opinion collected from domestic and international tourists and in-depth open-end interviews taken with influential tourism stakeholders. Even though there is not much that had been done to address the tourism innovativeness and marketing strategies from the academia and Government institutions in $\mathrm{Ne}-$ pal, this paper aimed to figure out the major pitfall and illustrate the suitable recommendation towards drafting the strategies and policies that can facilitate overall Nepalese tourism development. The subject is essential to ensure sustainable growth and to achieve the tourism national goal. Our study aimed to generalize the research gap by putting forward ITDM model which is the sum of idea generated from SOSTAC and Abernathy \& Clark innovation model. ITDM was casted forward after analyzing and reviewing the applicability for Nepalese tourism development context. The highlighted finding of this research can conclude that: "There is collaboration dysfunctionality among key stakeholders, disintegration of common goals within key stake holders, failure of high-level tourism council functionality, inadequate budget line, un-contextual vision lead mission, lack of skilled manpower, poor tourism infrastructures, aviation infra scarcity, low degree of ICT readiness, un-updated national
\end{abstract}


tourism policies, ignorance of triple helix correlation (GON, P.C, and Academia)". These major constraints should be immediately addressed in order to achieve and yield tourism development national goal of Nepal.

\section{Keywords}

Tourism Innovation, Marketing Strategies, Tourism Policy, ITDM, Nepal, SOSTAC, Abernathy \& Clark Model

\section{Research Background}

It is estimated that 21 st century's global economy will be driven by major service industries also called "3T" (Tourism, Technology (ICT) and Telecommunication). Travel \& Tourism generated US $\$ 8.272$ trillion (10.4\% of total global GDP), 1.6 trillion of total exports (7\% of world exports ${ }^{1}$ ) and 313.221 million jobs ( 1 in 10 jobs) for the global economy in 2017. Tourism is a multidimensional crucial development parameter of the world economy. Travel \& Tourism impact on the economic, social-cultural, environment and political scenarios of the particular country [1]. This overall comprehensive impact demonstrates the necessity of establishing public policy to guide, direct, co-ordinate and control the development of tourism in-order to minimize the negative impact and maximize the benefits. According to [2], Tourism Policy refers to an overall high level plan that includes goal and procedures; policies are generally found in formal statements such as laws and official documents and statements. Tourism policies are generally considered to be an area of nations overall economic policy, which is a public policy designed to achieve specific objectives relevant to tourism development of the country or region.

Tourism policies also evolve from the survey and analysis of present tourism development patterns, infrastructures, innovativeness, marketing activities and tourist market etc. Tourism powerhouse Nations, for example member countries of European Union, USA, China and Japan give tremendous attention towards sustainable tourism, innovativeness and scientific marketing (promotion) programs thru their policies and statements of tourism ecosystems. There are numbers of literature and grounded research e.g. [3]-[13] centrally focused on the role of public sectors (government institutions) stimulating the tourism innovation and lead the innovative marketing strategy which is unavoidable towards achieving tourism development national goal. The significance of Government involvement in tourism development, innovation and tourism marketing is irreplaceable because the Public policies are the key to assist making decisions and enforcement to prestigious international organization including, WTO, UNWTO, EU, OECD, WB, ADB, BRICS, AIIB and ASEAN, also gradually putting their efforts towards tourism development and innovation agenda, emphasizing ${ }^{1}$ https://www.e-unwto.org/doi/pdf/10.18111/9789284419876 
impetus of tourism towards world, regional, national, societal and grassroots individual synergetic well-beingness. The fundamental catalyst of overall tourism development in 21 st century can consider "tourism innovation and innovative Marketing", and thru the proper utilization of these elements (i.e. innovation \& innovative marketing), it can be the game changer for the tourism resource nation economic rejuvenation.

In tourism, public policies are related to co-ordination, planning, legislate, promotion, stimulation, allocate resources and solve the practical problems. Such policies are formalized for the development of plans, programs and agreements. In terms of tourism, public policies are aimed at growth of national income, generate employment, increase foreign exchange, ease for entrepreneurships, tourists to different areas (diversified development) enable spaces for tourism [14]. In this stance [15] more broadly defines that "Public policies on tourism are responsible for planning, development and promotion, while tourism marketing is responsible for attracting tourists to a destination, to develop new tourism products and services that meet tourists' needs and satisfaction". In the discourse of tourism marketing and innovation the government plays an important role along with private sector. Integrated actions and measures should be taken by both the public and the private sectors together in order to have common guidelines and strategies that meet the needs of both hosts and tourists [13]. More broadly natural and cultural resources, tourism marketing, innovation, prices, quality, FDI, tourism policies and skilled human resources are the pillar elements of the tourism destination competitiveness; whereas the government is the single authority which owns the legislative power to influence positively. The following info graph (Figure 1) of the UNWTO shows the impetus of public sectors (government) interconnection towards course of tourism.

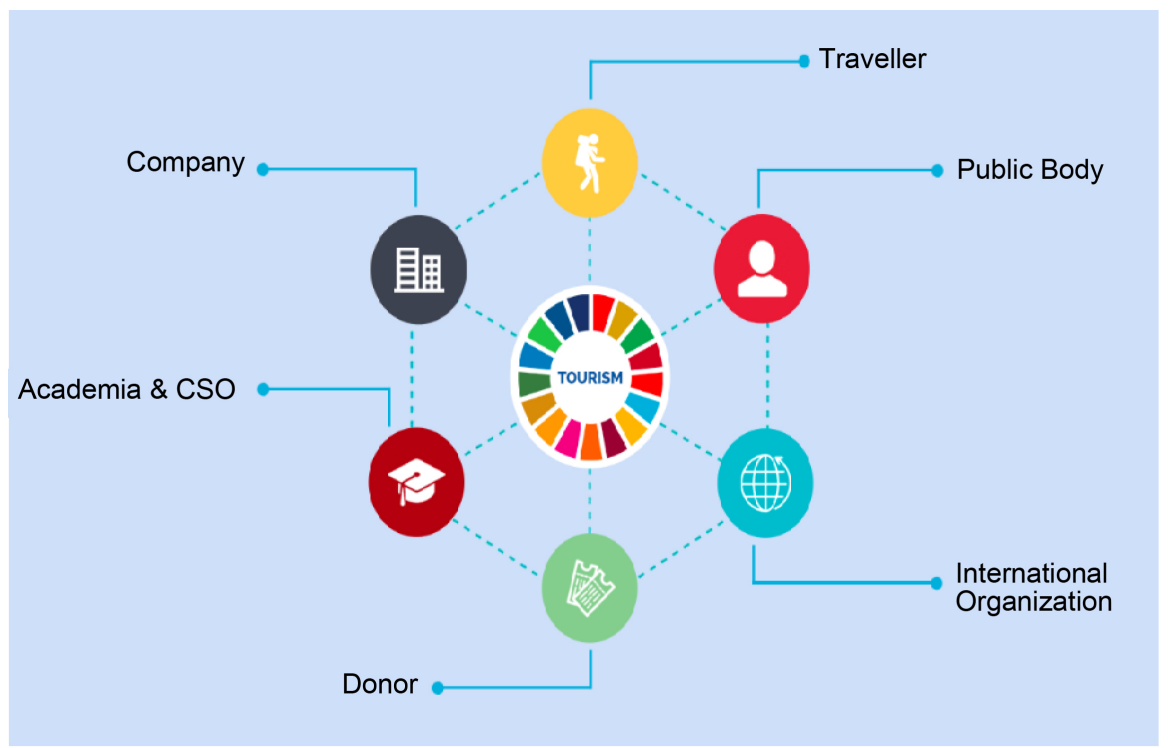

Figure 1. Interrelationship of tourism, academia and public institutions. Source: UNWTO. 


\subsection{Structure of the Article}

As a qualitative research paper, the core idea of this article is derived from earlier literatures noticeably from Abernathy \& Clark innovation model and PR smith SOSTIC Model. To justify the papers validity, required contextual data was gathered by means of open-ended, face to face interviews with multiple Nepalese tourism stakeholders (Chairperson of TAAN, CEO NATTA, Mountaineering Association Official, NTB Officials, Tourism Ministry Official, Private tour operators, tourists and political party youth leaders), reviewing of multiple legal documents of Nepalese tourism institutions, direct observation and reference from influential earlier literatures. This article also justifies the scope of tourism research interlinked with study of government policies study. It initially provides the background and importance of tourism for the tourism resource country, secondly, discusses the relationship of tourism and public policy, thirdly, it shows the panorama of Nepalese tourism discourse, and fourthly, it introduces the innovation and marketing importance for tourism development and presents the authors purposed model of tourism development contextual model applicable for Nepal. Finally, outlined conclusion, remark, suggestion, research gap and future research direction are addressed as well.

\subsection{Justification of Tourism Development and Its Scope with Public Policy Study}

Tourism may appear an unlikely topic for public administration but it is increasingly relevant to the public sectors. The role of the bureaucracy in tourism planning, implementation and monitoring can be critical in virtually all kinds of political systems [16]. Adjoining the earlier literature "Governments are facts in the modern world, it's only the governments which hold the power to provide the political stability, security and the legal and financial framework, which is essential's in tourism developments, hence tourism also one of the very important discipline of public administration" [17]. Acknowledging the synergetic positive impacts of the national economy from the tourism industries many countries have been giving significant importance on tourism around the world (developing world to developed economy), significant number of regional and international organization has been formed and active on tourism industry's future marking e.g. UNWTO, WTTC, WTCF, European union tourism council and PATA etc. according to the UNWTO the largest organization of world tourism there are one hundred fifty eight member countries, which also implies the necessities of the government administration and policies towards tourism. In general, tourism can define activity concerned with the temporary movement of people to destinations outside the places where they normally live and work, and activities during the stay at these destinations ${ }^{2}$. In other words, tourism is not only related with destination it also related with people movements which inte-

${ }^{2}$ http://www.tourismsociety.org/files/uploads/docs/Articles\%20of\%20Association\%202017\%20-\%20c urrent\%20version.pdf. 
gral part of government study. Tourism industry has experienced continued growth and deepening diversification to be become one of the fastest growing economic sectors in the world, as of today, tourism is the major economic turbine in the world economy, tourism industry contributing world $10 \%$ GDP, one of every ten jobs, 1.4 trillion export sum (7\% of world total exports) and 30\% of services exports [18]. To capitalize the vitality of the tourism industry the government is the key factor, which can formulate, implement and regulate overall tourism ecosystem in desire path.

Government involvement is arguably inevitable is any tourism development at national level, there is a paucity of studies focusing on public policies, innovation and development focusing tourism industry [19]. Recent studies suggest that the effective operation of the tourism economy highly dependent on Government institutional arrangements [20]. Evidence shows that tourism has become a very important and dynamic sector both in the world economy and particular in developing countries, its growth affects not only the activities directly linked to tourism but also other sectors; tourism is already an important sector in some developing countries and will become so for others. Developing countries have been fast growing in tourism industry terms in the world over the last decade. Tourism is one of the most important sectors in a large number of developing countries. Increases in economic growth, disposable income, creation of new employment, political stability, and fueled the significant growth of tourism [21]. Contemporary tourism is a very complex phenomenon that affects millions of people around the world. Among them are consumers, deliverers of tourist products or simply residents of reception areas. All of these people interact within the tourism ecosystem every day. In particular, the significance of tourism is emphasized in terms of importance to functioning of contemporary societies. Tourism is one of the largest sectors in global economy and in addition it is a specific designator of modern era to measure of quality of life. It is characterized by numerous ties with many branches of social and economic life. Tourism has a major influence on the use of space and character of infrastructure, boosts employment and regional development, and depicts strong ties with education, culture and healthcare. At the same time, it's heavily dependent on environment quality, transport, security, new technologies etc. All of these factors mentioned above suggest that tourism (in the last several decades) is highly recognized by the government and is considered one of the major elements of policy carried out at various levels of management and administration [22]. As aforementioned literature the Government is a key stakeholder of conceptualize, formulate, development, implement, negotiate and regulate authority of the public and also private institution. Policies always a guideline for the overall development activities of the entire economy cycle, Policies must be scientific and updated with world of scenarios subjective to context. Innovativeness and appropriate marketing technique driven policies can attempt utmost of the tourism development goals [9].

Why Nepal as Research Sample? 
Nepal is the country which is unique on a number of levels, perhaps the most important being its sheer natural beauty, cultural diversity and religious shrine (Lumbini the birthplace of Lord Buddha, numbers of Hindus temple \& pilgrimage sites). Country blessed with world's highest mountain range; it containing eight of the world's ten tallest mountains. Nepal is a magnet for the world's most avid mountaineers, rock climbers, trekkers, and adventure seekers, owing to the immense vertical drop from its northern mountains to its southern plains containing hotspot for climatic and biological diversity. Naturally, cultural array mirrors of geological and climatic varieties, e.g. Chitwan National Park a World Heritage Site, lays more than 500 species of birds, 50 spp. mammals and 55 spp. amphibians reptiles. Sagarmatha National Park Its lowest point is approximately 2800 meters; is home to over 100 species of birds and provides universal scenic views of flora and fauna. Nepal's biodiversity is not limited to land creatures. It is estimated that the country also has over 250 species of fishes in its vast river systems ${ }^{3}$. It also offers beautiful lakes, steep rivers and gorges, unique wildlife, historic monuments, impressive fine arts, significant religious sites and exotic cultures attracting a wide array of travelers for a variety of reasons [23]. According to the recent report and prestigious travel portal of the world Nepal is one the top 10 country which receipts 24.9 percentages of international tourists arrival growth ${ }^{4}$ also featured on Forbes news. Which is satisfactory indicator for the nation, however this figure relating of natural growth proxy of above mentioned blessed tourism resources. Government need take all measure serious and apply adequate policy and initiatives towards tourism development, which can be obvious of game changer for Nepal i.e. policy and administration study are more significant in Nepalese tourism development context where almost most lack of evidence that high level academic research approach carried forward in this regard.

\section{Review of Tourism Development Initiatives and Institutionalization in Nepal}

Tourism development has seen as dispersing geographically ever outwards from its origins in Britain and Western Europe, creating a series of "pleasure peripheries", and spreading socially from the upper classes, down through the middle ranks and ultimately to the mass working classes [24]. By the span of time tourism industry has spread the influence entire the world. Agents in this movement were social emulation, improvements in technology, awareness of education and accessible transportation. Nepal has been officially open for international tourism since 1951 and tourism sector today is an important employer and source of foreign currency generator ${ }^{5}$. However, the organized maiden tourism development planned initiative was taken place in only late 1972 A.D. along with drafting first Tourism master plan for the country. The first tourism master plan 1972 ${ }^{3}$ http://ibn.gov.np/tourism.

${ }^{4}$ https://edition.cnn.com/travel/article/world-most-popular-destinations-2017/index.html. ${ }^{5}$ http://cooperation.unwto.org/news/2014-05-27/national-tourism-strategy-plan-nepal. 
was drafted with the help of Germen tourism experts.

Nepal tourism master plan 1972 supplied the benchmark to access policy evaluation and project performance in tourism; conjunctive successive government of Nepal has been highly priorities the tourism sectors development; such as in 1998 GoN ministry of tourism celebrated "VSIT NEPAL YEAR" in order to promote Nepal tourism destination among international community, and also to encourage domestic tourism culture. 2011 remarked Nepal's tourism year, aiming to promote and facilitate domestic and international tourism development. In-between there were noticeable historical tourism incidents recorded such as: in 1949 first foreigner Mr Bill came to Nepal for trekking, in 1950 first French summiteer team succeed Mount Annapurn (Fishtail), 1951 Nepal has been officially open for Foreign tourists and the same year first hotel opened in Kathmandu valley, in 1952 opening of first international hotel, in 1953 first Himalayan airways operated and Mr. Edmund Hillary and Tenzing Norgay Sherpa summited Mt Everest, in 1965 first trekking company established and in 1967 UN general secretary Mr U. Thant visited birth place of Buddha Lumbini, in 1972 tourism masterplan drafted, in 1978 first tourism act endorsed, in 1992 foreign aid and technology transferring act introduced, in 1993 aviation policy drafted, in 1995 first tourism policy endorsed, in 1996 civil aviation act endorsed also Nepal tourism board (NTB) act enforcement in the same year, in 2006 civil aviation policy and 2008 tourism policy of Nepal endorsed. Likewise formulation of tourism corporate association emerged in1966 HAN and NATTA, in 1972 NATHM, in 1979 TAAN and 1989 NARA [12].

Ministry of tourism first came into the existence in 1978, in 1982 civil aviation was also merged into the ministry of tourism and it became the ministry of tourism and civil aviation. In 2000, cultural sector was also integrated in the ministry and called ministry of culture, tourism and civil aviation (MoCTCA) ${ }^{6}$. Ministry of culture, Tourism and civil Aviation acting in policy level, Department of tourism assisting to MoCTCA and acting as regulator and implementor. Nepal tourism board (NTB) solely authorized for promotion, marketing and branding Nepalese tourism destination among home and international arena (acting as regulatory and implementing level). Tourism sectors parallelly priorities by newly formulated federal governments (7 states in Nepal) by formulating ministry of industry, tourism, forestry and environment as a prominent federal cabinet ministry ${ }^{7}$.

Ministry of culture, tourism and civil aviation had lunched "TOURISM VISION 2020" in 2012. There are various tourism acts, policies, directives and rules are in legal effect such as tourism act 1978, the immigration act 1992, mountaineering expedition rules 2002, travel and trekking agency rule 2005, rafting rules 2006, hotel, lodge, restaurant, bar and tourist guide rule 1981, environment protection act 2007, tourism policy 2008 and tourism vision 2020 in 
2012. Most importantly newly promulgated "Constitution of Nepal 2015" assimilated the tourism policy as one of the principal federal policy. Concurrent GoN declared 2020 as a "visit Nepal year once again from the cabinet decision with setup target of welcoming two million international tourists. In amidst of march 2018 MoCTCA has introduced and taken account 100 days action plan towards reviewing hampering tourism development policies and airport infrastructures also upgrading only one running international airport (TIA) of Nepal. There exist few other initiatives which is forwarded by GON under the framework of regional tourism co-operation and tourism infrastructure development project for example south Asian tourism infrastructure development project (SATIDP) between Nepal, India and Bangladesh which is primarily focused on developing sub-regional bilateral and multilateral tourism circuits ${ }^{8}$, whereas Nepal's priorities should construct "Lord Buddha circuit", which can be equally beneficial for the subcontinents as well as Tibetan plateau tourism development.

\subsection{Conceptualize and Diagnosis of Nepalese Tourism Marketing Constraints}

According to the American Marketing association's definition “Marketing is the activity, set of institutions, and processes for creating, communicating, delivering, and exchanging offerings that have value for customers, clients, partners, and society at large". Marketing as a concept is evolving quickly and, interestingly for tourism, there is a growing trend to conceptualize marketing based upon services rather than physical goods. There are many definitions of marketing and they all focus around the need to identify and supply customer needs. Inevitably, definitions tend to reflect the prevailing thinking of the time. Many worldwide especially underdeveloped countries, in spite of possessing outstanding tourism resources, have not been able to market them successfully.

Developing a tourism marketing assessment provides a model for understanding the nature of their tourism product, their tourism competitive market position and resident needs and concerns. It will help determine how to allocate scare resources in order to achieve specific economic development objectives [25]. The term tourism promotion referred by defined term database "tourism promotion" means direct funding designated and spent solely for tourism, marketing of tourism or initiatives that, as determined in consultation with the local tourism industry organizations, attract travelers to the locality and generate tourism revenues in the locality. The role of Government involvement in tourism development and promotion always pays a vital role, as a public good, government's tourism marketing plays an important role in promoting national tourism images and tourism destinations. Four main factors have significant effect on government's tourism marketing, including motivation, market investigation capacity, synergy capacity of external network, and environmental policy

\footnotetext{
${ }^{8}$ http://satidpnepal.gov.np/index.php.
} 
interventions [26]. However, promotion level of Nepalese tourist destinations is relatively low in terms of scientific and professional perspective, when comparing to other tourism destination countries. Therefore, it becomes a key issue to strengthen the scientific guidance of the government in tourism destination marketing and enhance the public marketing performance. The future for tourism marketing deems more exciting one, because of the technological and social changing phenomena are continually providing new opportunities and challenges. Therefore, the role of government institution dealing with tourism sectors is very crucial. According to the [27] "Marketing is a subject of vital concern in travel and tourism because, in practical terms, it harnesses the power of massive commercial forces as well as government and regulatory influences" It is the principal management influence that can be used to shape the size and behavior of major growing global tourism market. Hence, we can generalize the terminology "tourism Promotion" also the integrated part of "Tourism Marketing".

Rapid changes in the competitive environment in the tourism have forced tourism destination to provide higher quality services and added the value to travelers [13]. Every tourism resource country willing to attract larger number of tourists, however achieving the target of receive larger number of targeted tourists inflows is a daunting task. Tourism marketing and promotion is the complex phenomena comparing with product marketing, it need a holistic approach to justify the weigh of service marketing. Tourism marketing has become a strategy developed by various National Government, cities and region it increased the competitiveness and attract the target Tourist group [28]. The phenomenon of the scientific tourism marketing by national institution has been common among developed countries, however less developed countries (e.g. Nepal) this is the quite new and more to achieve strategy. Recent year the technological tsunami bursting across the tourism industry and it will have profound implications on the travel experiences according to the earlier research by [29] "tourism enterprises, distribution channels, governments, researchers and consumers are the key factors of Tourism market development". He also stated that using of new information technology hold the power of fostering the global collaboration, co-operation and strategic alliances with in the tourism industry along new tremendous marketing opportunities.

\section{Innovation in Tourism Industry Conceptualizing the Terminology with Tourism Literature}

General understanding innovation means technological improvements either the invention of advanced equipment's; which is very limited and surficial understanding. As stated by [30] innovation did not equate to invention. [31] redefined that inventions were connected with basic scientific or technological research, while innovations were further developments of these, or just the application of bright ideas. According to the [32] definition "Innovation is the generation, acceptance and implementation of new ideas, processes products or ser- 
vices". Today's global marketplace is characterized by profound social, economic and technological changes. Change is ubiquitous and pervasive and innovation facilities' the process of adaption to many of these changes. Innovation plays a key role in nurturing the economy in enhancing and sustains high performance of each industry.

Researchers in each different discipline conceptualize innovation differently and have quite different views of its impact on an industry's productivity, growth and performance [33]. The study of innovation in services is still in its infancy seeing that the first studies only appeared in the late 1990s and it is difficult to find a robust theoretical framework for the study of innovation in this sector. It becomes even harder to find when applied to hospitality and tourism sector [34]. However, currently the topic "Tourism innovation" becomes the very hot topic for numerous researchers and Governments institutions. Today's Global traditional economic transactions are being replacing by digitalization; with the help of great improvements in ICT's. Tourism has being revolutionized by new technologies (internet bookings, online payments) and tourism has always been subjected to changes, reflecting shifts in taste and preferences, technologies and politico-economic conditions [35]. Most of the case literature revealed that the innovation and new trend on tourism derived from developed countries; third world countries tourism policymakers should encourage technology transfer and grab the new trend and innovation in-order to promote tourism industry. The use of online (internet) travel research and booking tools, paired with continued supply growth is opening new opportunities, almost two third of leisure travelers use online resources [36]. Hence the important of ICT on tourism industry is unavoidable tools for tourism development. Government should draft ICT friendly tourism policies that can help tourism Resources maximization in to the tourism markets thru out the innovation channel.

At present, the role of innovation in tourism is becoming a major strategy to gain competitive advantage of particular tourism destination of the various tourism nations. More studies in this area are necessary as the role of National government in such a process is still not well understood and highly grounded. In the word of [37] role of National government is essential to promote and facilitate tourism innovation in order to stimulate various networks and collaboration, so that collaboration with in the government, public private collaboration, collaboration with other peripheral industries and collaboration with in tourism industry operators. Innovation is the solution of the economic woes faced by developed and developing world across various industry sectors. The need of innovativeness has almost become a precondition for the survival, sustainability and future growth of modern industries including tourism [38]. It is very clear that innovation and entrepreneurship provide value to advancement and quality of the international tourism industry, for the less developed countries adding tourism innovation is an opportunity to differentiate the tourism product making it more competitive and increasing socio-economic gain at grassroots level 
[7]. We can conclude that tourism innovation not refers to radical invention it is the incremental improvement of activities within the whole tourism ecosystem; which can reduce the cost and meet the real needs of travelers more conveniently.

\section{Implacability of SOSTIC $®$ and Abernathy \& Clark Innovation Model: Nepalese Tourism Development Prospective}

As aforementioned the Government of Nepal has been recognized tourism sector is one of the key industry with vast potentiality aiming to be the game changer of Nepalese sluggish Economy. In another hand GON had been engaged drafting tourism policies and programs since 1972. Currently there exist multiple institutional arrangement, e.g. Ministry of culture, Tourism and civil Aviation as policy and long-term strategies formation body, Department of tourism (DT) and Nepal Tourism Board (NTB), government regional tourism offices, newly formed federal tourism ministry as a regulatory, promotion and implementation body. However, the overall Nepalese Tourism development is lagbehind the viability. in-order to maximizing the tourism yield from the reserve possibilities of Nepalese Tourism resources, this paper aimed to scientifically explore \& analyze tourism development, innovation and marketing practice as well as tourism polices drawbacks. To respond the current constraint of Nepalese tourism development and marketing planning very prestigious the SOSTAC $\mathbb{}$ marketing model deemed to very practical in order to capitalize the abundant tourism potentiality of Nepal. The SOSTAC ${ }^{\circledR}$ marketing model was introduced by PR Smith in 1990, is a popular and widely used model for marketing communication and strategic planning. This model is impetus usefulness either overall marketing strategic setting or digital marketing strategy buildup, whereas the SOSTAC stands for situation analysis, objectives setting, strategy buildup, tactics finding, action plan and control mechanism respectively [39]. This article centrally advocating the involvements of the Government institutions especially Nepalese case, the government solely can't go for business as a private sector but government policy makers need to aware overall SOSTAC marketing communication strategy elements during their policy draft and promotional budgeting and implementing process.

As shown in Figure 2, SOSTAC $\AA$ diagram Nepalese tourism accountable authorities for promotional and marketing agents (NTB Nepalese Tourism Marketing and promotion agent) need to adopt scientific analysis and implementation of each elements of the model. There are many initiatives taken by Nepalese tourism development institutions (public and private), however there is always weak presentation of clear mission and vision, surficial analysis of situation, which is fundamental goal of success. This research also revealed from the key interviewee and document reviewed that there is unclarity of the objective formulation via tourism authorities such as core direction towards SMART and innovative. 


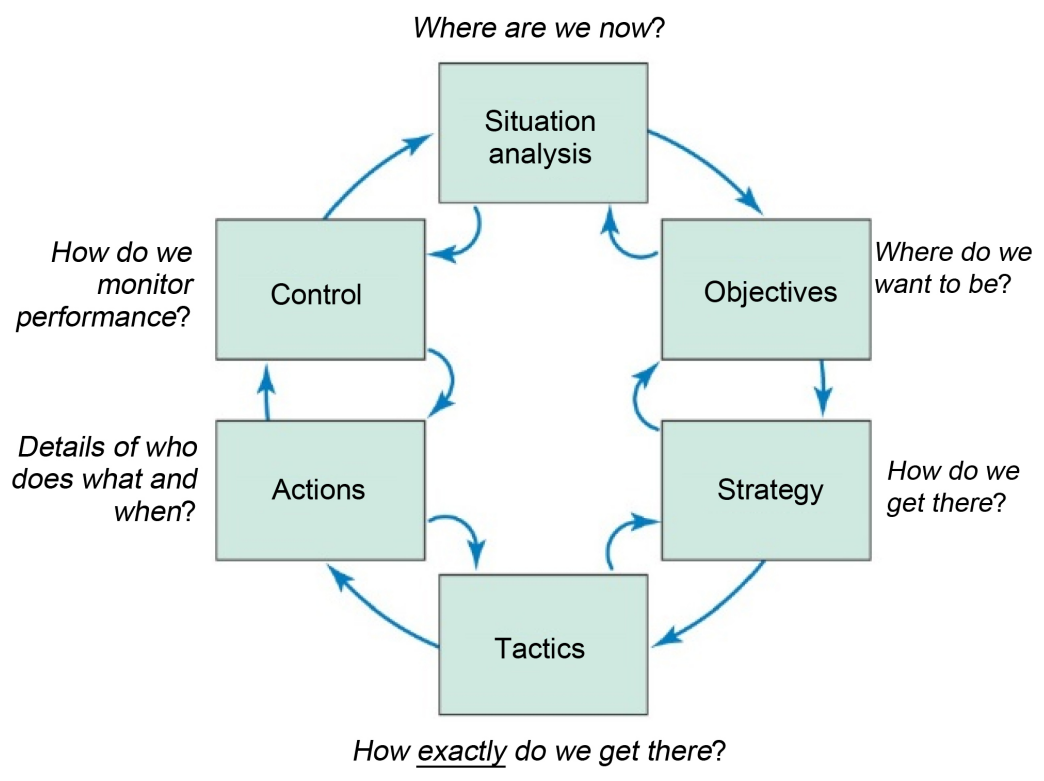

Figure 2. SOSTAC®Model. Source (PR Smith, 2005).

Traditional marketing and promotional strategy need to be replacing with scientifically approved and updated strategies such as introducing Nepalese contextual business model, segmentation of tourism market and priorities high yield target sources. likewise tactics should flexible with strategy and scientific, there is bitter truth in Nepalese tourism development major concern by respondents was action and control mechanism; lack of co-ordination between the major stake holders among internal and external tourism players, rigid assignment delivery accord to their personnel specialization, traditional and so called formality on control and tallying systems which is unavoidable for future planning and development of Overall tourism development of Nepal.

\section{Abernathy and Clark Innovation Model's Applicability for Nepalese Tourism}

Competitiveness depends to a large extent on innovation which can applicable in tourism also [40]. This portion of article focuses on the differences in innovations implemented in the field of tourism industry in Nepal. innovation provide essential value to the advancement and quality of the international tourism industry, it is obvious that for less economic countries (LEDC) tourism innovation is an opportunity to differentiate the tourism product and making more competitive with a little initiatives and strong implication via national government.

21 st century global economy underwent strong technological changes moving towards IT-based flexible structures [8]. Much more innovation introducing in service sectors however especially third world countries like Nepal always remain lack of the benefits of tourism (service) innovation, in-order to enlarge market share and tourism product development. It is very important for policy maker to introduce and facilities tourism innovation in every step of the tourism 
development discourse to be successful in tourism development goal [9]. Abernathy and Clark approach of innovation, scientifically transformed to the tourisms innovation by [41] based on Original [42] model explain that existing specific product or services innovations whether obsolete or entrenchment in the current time, in some cases old ideas and qualifications become outdated and need to be replaced, while other cases development of existing structures are more relevant. In short, this model illustrates four types of innovations: Regular, Niche, Revolutionary and Architectural innovations.

As shown in Figure 3, the essence of Abernathy and Clark model is radical innovations can disrupt and make existing competence obsolete, incremental innovations conserve and entrench existing competences. The major four points of above presented matrix can be concluded in brief with applicability for Nepalese tourism as following.

Regular innovation: regular innovation can help economies the existing technology and market. The scale of regular innovation adoption leads the dramatical changes on advancing the existing quality, improving the tourism features and removing the bottlenecks. In the Nepalese tourism industry regular innovativeness can acquired through Promoting new investments that raise productivity, Training proprietors and staff to operate more efficiently and Incremental raise of quality and standards.

NICHE innovation: in tourism NICHE innovation refers to introducing new tourism product increments towards existing market and new markets segments as well. Countries like Nepal there are abundant possibility applying NICHE tourism products. The management must nurture quick footed capability to promote the entry of new entrepreneurs to exploit business opportunities, encourage tourism, firms to enter new marketing alliances and combine existing products in new ways in order to strive maximum profit.

Architectural innovation: according to the http://provenmodels.com/ description the use of new concepts in technology to forge new market linkages forms the essence behind architectural innovation. New technology that departs from established systems of production and, in turn, opens up new linkages to markets and users, is characteristic of the creation of new industries as well as the reformation of old ones.

Revolutionary innovation: Innovation of this sort defines the basic configuration of product and process and establishes the technical and marketing agendas that will guide subsequent development. The policy makers of Nepalese tourism development need constantly scan the technological development on the tourism ecosystem, create the new events and attractions that demand a reorganization, redefining the physical or legal infrastructure in order to unmet the market needs. In a line this model highly beneficial for developing countries because of innovation deficits (radical change), so that at same time continually and carefully introduced incremental innovation (changes) which is very basic for Nepalese tourism industry development. 


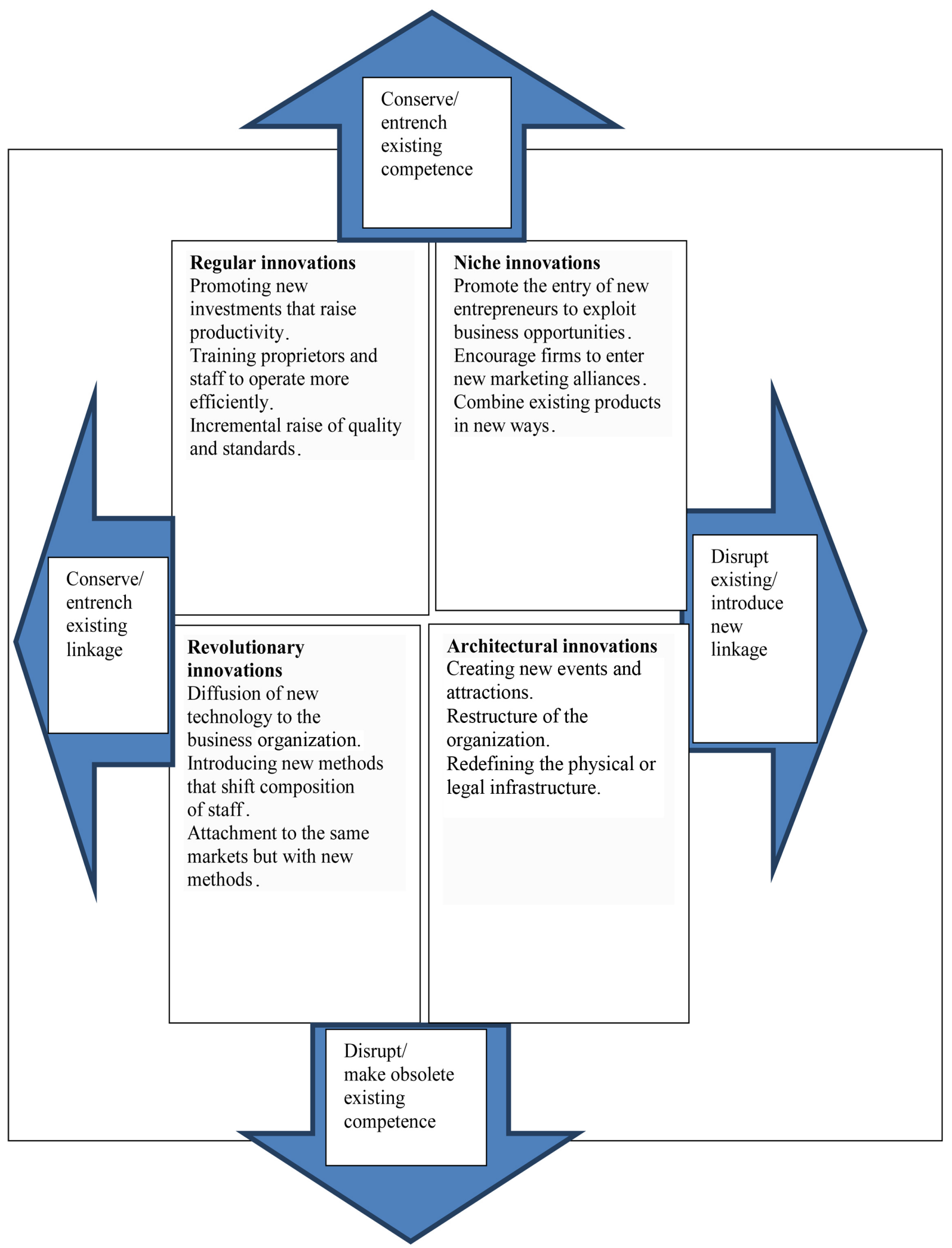

Figure 3. Abernathy and Clark Model. Source: tourism impeccability introduced by Hjalager 2013. 


\subsection{Purposed Forwarding Construction of Practical Model for Nepalese Tourism industry Development}

Many well-known and highly expertise theory some case cannot be consent and applicable for different political and geographical scenarios. After discussing above presented two prestigious models and in addition of gathered information from this research, I'd like to purposed forward following sketched generalized model for Nepalese tourism development which can be consider very practical and contextual for Nepalese tourism industry scenario. As shown in Figure 4. The terminology of my sketched model phase-I shows IPO (input, process and output) model with appendage of Evaluation in every steps of the tourism development discourse. As a inputs policy should be daft with clear mission and smart vision, as a process innovative actions need taken towards implementing activities, output should tallying with expected outcome and regular evaluation need in every steps. Evaluation must be flexible and contextual so that can amend in time and switching to another better alternative.

Phase-II: amalgamation of innovation and marketing is the core idea of the phase two. Whereas left hand side innovation refers to tourism product innovation, process innovation, tourism institutions innovation and tourism marketing

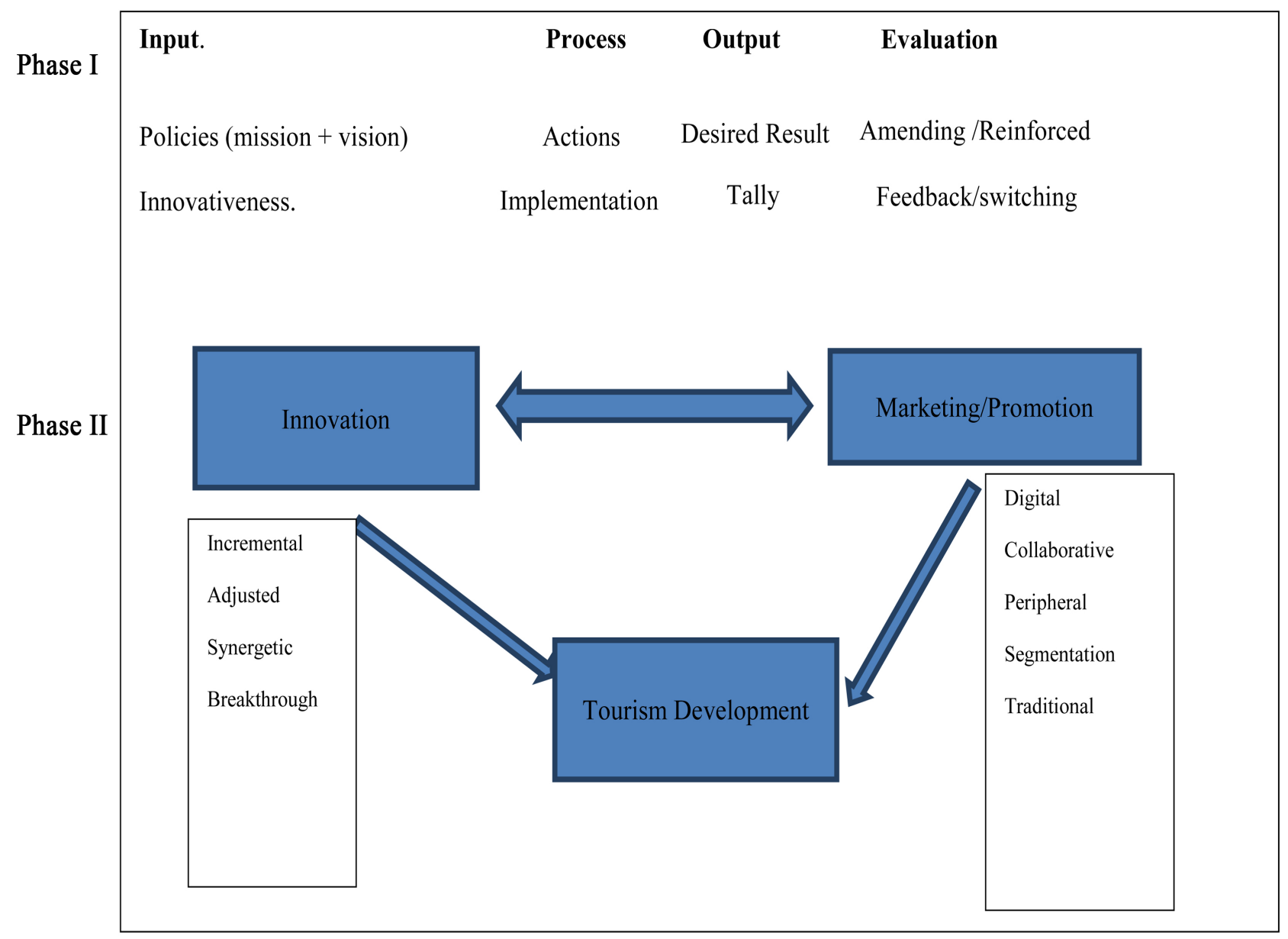

Figure 4. Integrated Innovative Tourism Development Model for developing country (ITDM). Source: Author own work. 
innovation. For the Nepalese tourism (most of developing countries) development context the fundamental hindrance is deficits of budget line for introducing new technology, miss-management of available resources, weak tourism infrastructure and improper tourism marketing techniques. Taking account these pitfalls of the tourism development innovation management should priorities and implement Incremental, adjusted, Synergetic and Breakthrough (i.e. incremental: regular increments, adjusted: flexible upon the situation, synergetic: applying the innovation which can have multiplier positive effects, Breakthrough: create own technology which can be novel either modified) approach of steps respectively.

In the right-hand side marketing refers to the integrated innovative marketing and promotion initiatives vis National government and its responsible institutions. In this new century tourism destination marketing emerges as a key issue around world because of the high level of destination competition, there indeed a scientific and contextual marketing technique in order to enrich targeted tourist generating region. Each sub point on my purposed model marketing model are equally significant for Nepalese tourism international enrich (i.e. most of developing nations) and marketing success. The access of digital marketing(e-tourism) is very limited and very basic in Nepalese tourism marketing practice, NTB mostly depend on traditional marketing tools (MICE, Brochure TV/Magazine advertisement etc.) with the help of advanced ICT advancements tourist precipitant country should have more focus on e-tourism and e-tourism marketing. Because the international tourists have more approaches with digital communication channel rather than traditional means. internal and external mutual collaborative marketing technique create high level of communication dispersion towards target audience, peripheral marketing strategies are equally impetus for domestic and international tourism development, for the Nepalese tourism there is vast potentially because Nepal proximity with world largest tourist generation countries China and India. Marketing policy should be segmented with the demand of different tourist generation clusters. At the same time, traditional technique of marketing is also valid for domestic tourism development in the case of developing countries.

\section{Finding, Conclusion and Recommendations}

Tourism development discourse is critical and multifaceted that requires an interdisciplinary and integrated approach, which must be supplemented by continuous and systematic research in to all aspects of tourism. Fundamentally, "Innovation and Marketing" are the two key factors for tourism success in the $21^{\text {st }}$ century [43] [44] [45]. For a developing nation, it is a daunting task to make a new technology or upgrade an existing technology because of deficits of finance and lack of skilled manpower [45]. The small scale of incremental innovation and readiness of transferring innovative marketing technology can lead to a big positive change on tourism development for developing countries. Nepal is a 
true symbol for the high competitive and diversified tourism destination of the world for adventure seekers. The outreach and gross receipts for the tourism industry in Nepal are negligible in spite of the high potentiality of high-end tourism yield. Taking reference from [46] matrix contents and applied for Nepalese tourism industry development the major findings are presented in Table 1.

Table 1 presented Nepalese tourism developmental major constraints results (finding) of this research work provided strong evidence that Nepalese tourism development discourse seeks multiple integrated assignments in order to yield from tourism sectors, improved and competitive tourism industry equally impetus for overall Nepalese economy rejuvenation. Hence, there is a necessity of policies and actions, ambidexterity towards branding, marketing, innovation, focused programs, improvement of business investment, human resource development, infrastructures development, improvement of tourism quality, reforms of institutional set-up \& management, conservation of cultural heritage and zero carbon target [47]. This research equally vows that there is miserable situation of ground transportations and aviation infrastructures in Nepal [48].

Based on this research finding, we like to suggest that: policies towards mountaineering and adventurous tourism should upgrade and regulate effectively, innovate the tourism attraction, amenities, accessibility and pricing, at the same time digitize the promotional techniques (ICT-focused), activate tourism council towards functionality, redefine FDI on tourism enterprises, update and implement advanced tourism technologies, encourage skill development and provide incentives towards tourism business for youths, increase the channels of co-operation and collaboration mode of tourism promotion campaign, facilitate the tourism research and measure the result with better implementation, "emphasize the e-WOM (online world of Mouth) platforms which is psychologically important for Place attachments" [49], introduce novel seeking adventurous niche destination, encourage collaboration with multinational tour operators, (big size OTA, TMC, DMC, MICE, car-sharing and NTO's), regularize organizing international events, upgrade modern looking multilingual website, promote and facilitate online booking and payment, take advantage of Search Engine Optimization (SEO), promote natural healing tourism, pay more focus on INDOCHINA+ASEAN tourism resource market, extend marketing activities in to more geographic potential source market, support aviation modernization and route development, target high performing client segments, improve quality (QAS), expand commercial and G2G partnership and strategic partnership, unified strategic priority should have carried forward along industry, government body and corporate partners, stimulate the investment on tourism sectors by commercial banks, improving and expanding the connectivity and destination infrastructures, uplift the public private partnership with community involvement, prioritized tourists security and safety measures and perseveres of natural, cultural and heritage, improve dissemination of tourism information, encourage domestic tourism by means of incentives, improving reception facilities, ease and waive the acquisition of visa policy and enriching the tourist content of the 
Table 1. Research Findings.

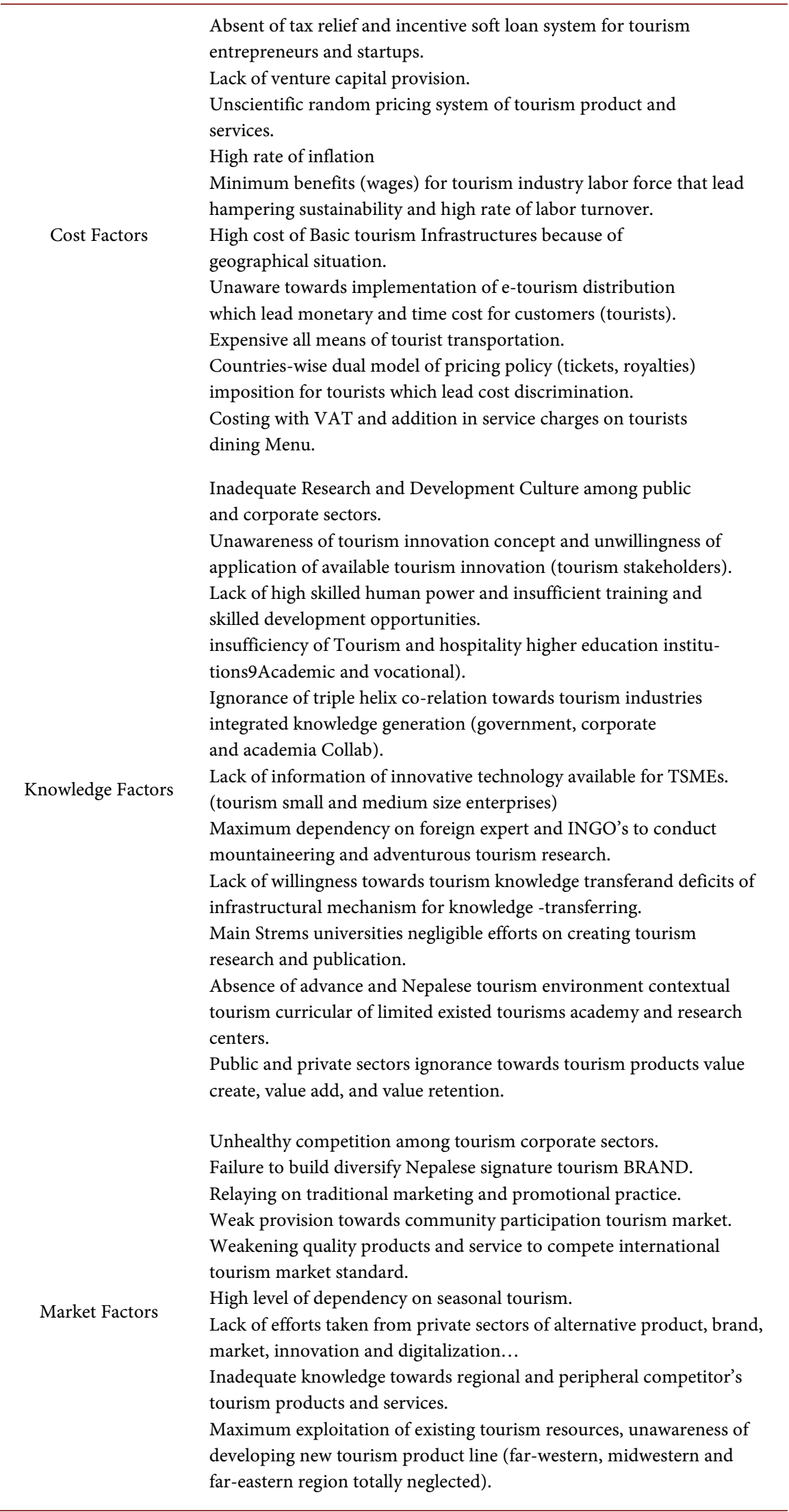




\section{Continued}

Market Factors

Intuitional Factors
Rigidness to build of adventurous niche destination, products and services for emerging tourism market.

Ignorance towards advancements of DMO's and NTO's website as an effective marketing tool.

Private sectors failures to make alliance and co-operation with international travel giant OTA, TMC, DMC and ride-hailing service providers.

Inadequate promotional and sales mission carried out by NTB and tourism corporate sectors associations.

Inadequate market segmentation, digitalize promotion, and cross-border tourism market cooperation.

Authority ownership illusion between national, provincial and local. Layers of Government's.

Weak of implementation of Tourism policies and strategic plans. Reoccurrence of corruption allegation cases especially GoN's high level aviation leadership and authorities.

Lack of unified solidarity between main stream political parties and influential intuitions towards tourism long term development plans. Unnecessary taxation and royalty's imposition by layers of government. Dysfunctionality of high level tourism council. Lack of speedy co-ordinations between Tourism ministry (MoCTCA) and other responsive ministries.

Traditional immigration clearance rules and visa issuance systems.

Co-ordination and egoistic problems between major private sector tourism organizations.

Weak management and fund mobilization for reconstruction of collapsed monuments from earthquake 2015.

Unfavorable taxation policies and procedures upon tourism sectors.

Vague federal governments tourism initialization and management.

Unnecessary lengthy and complicated rules for Tourism FDI. (limited tourism sectors opened for foreign nationals) Controlled FDI on tourism industry limited on hotel and casino business.

Major deadlock towards periodic evaluation and investigation of strategic plan \& policies.

Ignorance of gender gap issues among major tourism policies, directives, acts and rules.

Lack of coherence between changing market need and distribution channel while draft policies.

Policy Factors
Insufficient mobilizing strategies towards overseas diplomatic missions for tourism promotion.

Very weak aviation security standard and policies implementation mechanisms that lead to frequent crashes. Limited and restricted night hour tourism business policies. Outdated tourism policies for innovativeness and changing world tourism ecosystems Contradicting and overlapping relation towards tourism ministry's and sub-ordinate government institutions tourism policies.

Policy gap to deal Unnecessary political party wise labor organizations with in tourism sectors. 


\section{Continued}

\begin{tabular}{ll}
\hline Ignorance of tourism sustainability approach. \\
Lack of tourism satellite accounts. \\
weak tourism infrastructures. \\
Major deficit of advanced aviation service and international airports. \\
Insufficiency of National Flag carrier aircrafts, limited air route (zero \\
long-haul) and international easy access for national flag carrier (NA). \\
Insufficient relief and rescue mechanism in risk and disasters. \\
Insufficient tourist police and security arrangements for international \\
tourists. \\
Ignorance the role of Nepalese diaspora to promote Nepalese tourism. \\
Relaying on cash-based transactions, lack of infrastructures for digital \\
payments for international tourists (especially based on Chinese tourists \\
respond) \\
Lack of integrated tourist information center (traditional as well as \\
digital) \\
Inadequate evaluation and monitoring mechanism, policies and rules \\
only beautifully articulate on the paper. \\
Over politicization towards major tourism development committees and \\
tourism development trust. \\
Lack of initiatives to attract high value tourists segment.
\end{tabular}

global influential media, promoting tourism investment fund, establish NTB's overseas offices and nominate marketing representatives in various parts of the world, encourage Nepalese diaspora for tourism contribution, host trip for international celebrities, implement tourism satellite system, being alert on immediate update and renewal available tourism infrastructures. Nepal planning commission should draft and prioritize long-term tourism infrastructures, bring the incentives towards attracting offseason tourists, well management of Nepal national flag carrier, policy should prioritize the night-hour tourism, e.g. especial tourism zone 24/7 business hour with government full security, build the fast tract co-ordination mechanism of government tourism institution (national-regional-provincial-local level government) etc. in a line integrated tourism model, and policies, plan and actions should be directed towards sustainability, innovativeness and accessibility. The existence of big knowledge gap will lure the academia and research community towards high level of pragmatic and quantitative research to solve the Nepalese tourism developmental constraints.

\section{Acknowledgements}

The first Author highly acknowledge financial support for this project provided by the CAS-TWAS presidential fellowship in order to get enrollment as a full time $\mathrm{PhD}$ candidate at University of Science and Technology China. Research expenses covered from the first Author monthly stipend.

\section{Conflicts of Interest}

Authors declared that there is no any conflict of interest.

\section{References}

[1] Batala, L.K., Regmi, K. and Sharma, G. (2017) Cross Border Co-Operation through 
Tourism Promotion \& Cultural Exchange : A Case Study. Open Journal of Business and Management, 5, 105-118. https://doi.org/10.4236/ojbm.2017.51010

[2] Gee, C.Y., Fayos-Sola, E., et al. (1997) International Tourism: A Global Perspective (E. F.-S. Chuck y. Gee, Ed.). World Tourism Organization, Madrid.

[3] Hall, C.M. (1994) Tourism and Politics: Policy, Power and Place. In: Hall, C.M., Ed., Tourism and Politics. Policy, Power and Place, John Wiley \& Sons, Chichester. https://www.cabdirect.org/cabdirect/abstract/19951800176

[4] Hall, M.C., Williams, A. and Williams, A. (2008) Tourism and Innovation (Michael C. Hall, Allan Williams, Eds.). Routledge, London. https://doi.org/10.4324/9780203938430

[5] Akama, J.S. (2002) The Role of Government in the Development of Tourism in Kenya. International Journal of Tourism Research, 4, 1-14. https://doi.org/10.1002/jtr.318

[6] Qin, Q., Wall, G. and Liu, X. (2011) Government Roles in Stimulating Tourism Development: A Case from Guangxi, China. Asia Pacific Journal of Tourism Research, 16, 471-487. https://doi.org/10.1080/10941665.2011.597573

[7] Carlisle, S., Kunc, M., Jones, E. and Tiffin, S. (2013) Supporting Innovation for Tourism Development through Multi-Stakeholder Approaches: Experiences from Africa. Tourism Management, 35, 59-69.

https://doi.org/10.1016/j.tourman.2012.05.010

[8] Weiermair, K. (2004) Product Improvement or Innovation: What Is the Key to Success in Tourism? https://www.researchgate.net/publication/242488511

[9] Genç, R. and Genç, E.A. (2017) Market-Oriented Innovations in Tourism. Research in Hospitality Management, 7, 51-57. https://doi.org/10.1080/22243534.2017.1355606

[10] Korres, G.M. (2008) The Role of Innovation Activities in Tourism and Regional Growth in Europe. Tourismos: An International Multidisciplinary Journal of Tourism, 3, 135-152. http://mpra.ub.uni-muenchen.de/25380/

[11] Sandybayev, A. (2016) Strategic Innovation in Tourism. A Conceptual and Review Approach. International Journal of Research in Tourism and Hospitality (IJRTH), 2, 5-10.

[12] Ministry of Culture, Tourism and Civil Aviation of Nepal (2016) National Tourism Strategic Plan of Nepal 2016-2025. Kathmandu.

[13] Martínez, R.M., Galván, M.O. and Lafuente, A.M.G. (2014) Public Policies and Tourism Marketing. An Analysis of the Competitiveness on Tourism in Morelia, Mexico and Alcala de Henares, Spain. Procedia-Social and Behavioral Sciences, 148, 146-152. https://doi.org/10.1016/j.sbspro.2014.07.028

[14] Velasco González, M. (2005) Does Tourism Policy Exist? Government Action in the Field of Tourism in Spain (1951-2004). Política y Sociedad, 42, 169-195. http://revistas.ucm.es/index.php/POSO/article/viewFile/POSO0505130169A/23035

[15] Kottler, P., et al. (2011) Marketing Turístico (Alberto Cañizal and María Varela, Ed.). 5th Edition, Pearson, London and New York. http://www.pearsoneducacion.com/

[16] Linda, K.R. (1989) The Politics of Tourism in Asia. Vol. 1, University of Hawaii Press, Honolulu.

[17] Elliott, J. (1997) Tourism: Politics and Public Sector Management. Routledge, Abingdon-on-Thames.

[18] UNWTO (2017) UNWTO World Tourism Barometer January 2017 Excerpt. World 
Tourism Organization UNWTO (Vol. 13).

[19] Mei, X.Y., Arcodia, C. and Ruhanen, L. (2012) Towards Tourism Innovation: A Critical Review of Public Polices at the National Level. Tourism Management Perspectives, 4, 92-105. https://doi.org/10.1016/j.tmp.2012.05.002

[20] Tang, X. (2017) The Historical Evolution of China's Tourism Development Policies (1949-2013): A Quantitative Research Approach. Tourism Management, 58, 259-269. https://doi.org/10.1016/j.tourman.2016.03.010

[21] Islam, N. (2012) Tourism Marketing in Developing Countries: A Study of Bangladesh. University of Strathclyde, Glasgow.

[22] Alejziak, W. (2014) National and International Tourism Policy in the Face of 21st Century Challenges. Scientific Journal of Economic Problems of Tourism, 4, 86-100.

[23] Nepal Investment Board (2016) Investment Guide 2016. Vol. 44, Kathmandu Nepal.

[24] Heller, V.L. (1996) Designing a Tourism Marketing Assessment for San Antonio, Texas. Journal of Vacation Marketing, 2, 163-175. https://doi.org/10.1177/135676679600200206

[25] Louis Turner, J.A. (1975) The Golden Hordes: International Tourism and the Pleasure Periphery. Constable, London.

[26] Song, H. and Jiang, W.Y. (2015) Implementation Mechanism and Paths Selection of Government's Tourism Marketing: An Exploratory Research Based on Grounded Theory. Tourism Tribune, 30, 22-31.

[27] Middleton, V.T.C., Fyall, A. and Morgan, M. (2010) Marketing in Travel and Tourism 4th Edition. Annals of Tourism Research, 37, 280-281.

https://doi.org/10.1016/j.annals.2009.10.006

[28] Eshuis, J., Braun, E. and Klijn, E.H. (2013) Place Marketing as Governance Strategy: An Assessment of Obstacles in Place Marketing and Their Effects on Attracting Target Groups. Public Administration Review, 73, 507-516. https://doi.org/10.1111/puar.12044

[29] Hawkins, D.E., Leventhal, M. and Oden, W.L. (1996) The Virtual Tourism Environment. Utilisation of Information Technology to Enhance Strategic Travel Marketing. Progress in Tourism and Hospitality Research, 2, 223-238. https://doi.org/10.1002/pth.6070020304

[30] Phan, P.H. (2004) Entrepreneurship Theory: Possibilities and Future Directions. Journal of Business Venturing, 19, 617-620. https://doi.org/10.1016/j.jbusvent.2003.09.001

[31] Schumpeter, J.A. (2006) Business Cycles: A Theoretical, Historical, and Statistical Analysis of the Capitalist Process. Martino Pub.

[32] Thompson, V.A. (1965) Bureaucracy and Innovation. Administrative Science Quarterly, 10, 1. https://doi.org/10.2307/2391646

[33] Gopalakrishnan, S. and Damanpour, F. (1997) A Review of Innovation Research in Economics, Sociology and Technology Management. Omega, 25, 15-28. https://doi.org/10.1016/S0305-0483(96)00043-6

[34] Carvalho, L. and Costa, T. (2011) Tourism Innovation-A Literature Review Complemented by Case Study Research. International Conference on Tourism and Management Studies, Algarve, 26-29 October 2011, Vol. 1, 23-33.

[35] Löfgren, O. (1999) On Holiday a History of Vacationing California Studies in Critical Human Geography. University of California Press, Los Angels, London. https://doi.org/10.1525/california/9780520217676.001.0001 
[36] World Travel \& Tourism Council (2017) Coping with Success: Managing Overcrowding in Tourism Destinations.

https://www.wttc.org/-/media/files/reports/policy-research/coping-with-success--manag-

ing-overcrowding-in-tourism-destinations-2017.pdf?la=en\%0Ahttps://sp.wttc.org/a bout/\%0Ahttps://sp.wttc.org/about/

[37] Mei, X.Y., Arcodia, C. and Ruhanen, L. (2013) Innovation and Collaboration: The Role of the National Government in Norway. Tourism Analysis, 18, 519-531. https://doi.org/10.3727/108354213X13782245307713

[38] Divisekera, S. and Nguyen, V.K. (2018) Determinants of Innovation in Tourism Evidence from Australia. Tourism Management, 67, 157-167.

https://doi.org/10.1016/j.tourman.2018.01.010

[39] Paul, R. and Smith, Z.Z. (2011) Marketing Communications Integrating Offline and Online with Social Media. 5th Edition, Kogan Page Publishers, London, Philadephia, New Delhi.

[40] Kozak, M.W. (2017) Innovations in Tourism Policy: The Case of Poland. Journal of Tourism, Culture and Territorial Development, 8, 160-177.

[41] Hjalager, A. (2002) Repairing Innovative Defectiveness in Tourism. Tourism Management, 23, 465-474. https://doi.org/10.1016/S0261-5177(02)00013-4 http://www.sciencedirect.com/science/article/pii/S0261517702000134

[42] Abernathy, W.J. and Clark, K.B. (1985) Innovation: Mapping the Winds of Creative Destruction. Research Policy, 14, 3-22.

https://doi.org/10.1016/0048-7333(85)90021-6

[43] Rodríguez, I., Williams, A.M. and Hall, C.M. (2014) Tourism Innovation Policy: Implementation and Outcomes. Annals of Tourism Research, 49, 76-93. https://doi.org/10.1016/j.annals.2014.08.004

[44] Stamboulis, Y. and Skayannis, P. (2003) Innovation Strategies and Technology for Experience-Based Tourism. Tourism Management, 24, 35-43. https://doi.org/10.1016/S0261-5177(02)00047-X

[45] Eli Avraham, E.K. (2016) Tourism Marketing for Developing Countries. Palgrave Macmillan, New York. https://doi.org/10.1057/9781137342157

[46] OECD and Eurostat (2005) The Measurement of Scientific and Technological Activities Oslo Manual Guidelines for Collecting and Interpreting Innovation Data. Third Edition, OECD and Eurostat, Oslo. https://www.conicyt.cl/wp-content/uploads/2014/07/Manual-de-Oslo.pdf

[47] UNWTO and OAS (2018) Tourism and the Sustainable Development Goals Good Practices in the Americas. Madrid.

[48] Khadaroo, J. and Seetanah, B. (2008) The Role of Transport Infrastructure in International Tourism Development: A Gravity Model Approach. Tourism Management, 29, 831-840. https://doi.org/10.1016/j.tourman.2007.09.005

[49] Litvin, S.W., Goldsmith, R.E. and Pan, B. (2008) Electronic Word-of-Mouth in Hospitality and Tourism Management. Tourism Management, 29, 458-468. https://doi.org/10.1016/j.tourman.2007.05.011 